\title{
Diet and exercise performance in the horse
}

\author{
BY DAVID L. FRAPE \\ NS Research, The Priory, Mildenhall, Suffolk IP28 7EE
}

The rate of energy expenditure in maximal physical activity is fifty times that occurring at rest. Thus, a consideration of the manipulation of diet to influence physical performance should enquire into dietary energy and its metabolism. It is self-evident that a failure to meet the horse's energy requirements, as estimated by INRA (1990) and National Research Council (1989), will result in a chronic loss of body mass, debility and a decline in physical ability. In a survey of racing Standardbreds (STB) (Gallagher et al. 1992a) the daily intake of digestible energy (DE) was found to exceed the National Research Council (1989) estimate by $27 \%$, and so compliance with chronic energy needs is generally assessed by degree of fatness.

Thoroughbred (TB) horses of moderate fatness apparently use depot fat as a source of energy more effectively than thin or fat horses, as indicated by reduced glycogen expenditure during exercise at a heart rate of 200 beats per min (bpm) (Scott et al. 1992). Nevertheless, it is unclear how athletic ability is affected by an abnormally large dietary energy intake for a brief period, when fat deposition will change little. Thus, a distinction is drawn between acute and chronic effects of diet on athletic response (Frape, 1988). Changes in this response are hard to demonstrate because they are difficult to replicate on the track. Even using a standardized treadmill Plummer et al. (1991) found a mean coefficient of variation of $9 \cdot 6 \%$. Moreover, differences exist between relative solo-run times and a run time in competition, which has a potent influence on performance of TB (Harkins \& Kamerling, 1992). Therefore, despite greater precision of laboratory measurements, performance in competition is not reliably predicted. Yet noncompetitive work is an important function that can justify laboratory measurements to unravel the role of diet in work output.

\section{POSTPRANDIAL DIGESTION AND FERMENTATION}

Processing of cereals can influence digestibility and, therefore, the proportions digested and fermented. Processing of roughage can accelerate rate of passage, reduce gut fill, but decrease hindgut utilization (Wolter et al. 1975, 1977, 1978). The extent to which feed is fermented will influence the weight of ingesta. Slade (1987) measured the speed of Quarter horses galloping at up to $19.6 \mathrm{~m} / \mathrm{s}(44 \mathrm{mph})$ over $137 \mathrm{~m}$ or $229 \mathrm{~m}$ from a running start. Speeds differed according to the digestibility of feeds, as reflected by differences in gut fill.

The extent to which cereal starch provides glucose, or volatile fatty acids (VFA), depends on its precaecal, and even its pre-ileal digestibility. Kienzle et al. (1992) reported that the pre-ileal digestibility of oat starch was higher than that of maize starch, with similar degrees of processing. Grinding of whole grain led to high pre-ileal digestibility for oats amounting to $98.1 \%$ and for maize $70.6 \%$; rolling, or breaking, had little effect. Starch gelatinization enhances its small intestinal digestion, but only at moderate or high rates of intake. At low intakes most sources of starch are digested in the small intestine (Potter et al. 1992a). 


\section{ENERGY SUBSTRATES AND EXERCISE}

Energy for muscle contraction is derived from creatine phosphate (CP) and ATP. TB possess a high proportion of phosphocreatine $(\mathrm{PCr})$-rich fast-twitch fibres in skeletal muscles (Harris \& Hultman, 1992), so that loss of adenine nucleotides (AN) during intense exercise is greater than in man. After repeated gallops a $50 \%$ loss of ATP was recorded (Harris et al. 1991c, 1992; Sewell \& Harris, 1991), associated with a decrease in running speed and fatigue (Harris et al. 1991b), and with lower glycolytic rates and muscle ATP:ADP. The accumulation of ADP stimulates AN degradation to inosine monophosphate (IMP) with an increase in plasma $\mathrm{NH}_{3}$ concentration. There is a critical $\mathrm{pH}$ below which ADP rephosphorylation declines, $\mathrm{PCr}$ acting both as an intracellular buffer and as a reservoir for this rephosphorylation. Supplementation of human subjects with creatine monohydrate has increased muscle total creatine and PCr contents (Harris et al. 1992). The energy reserves for this synthesis depend on training, diet and the inherent characteristics of the horse. ATP resynthesis fuelled by fatty acid (FFA) oxidation is slow, so inadequate glycogen storage in active muscle fibres causes early fatigue despite an abundance of FFA. With increasing rates of energy expenditure the preference for glucose as a substrate increases, although the proportions of glucose and FFA used change rapidly with distance (Harris et al. 1987). Glycogen stores apparently do not limit sprint performance following training, which can increase glycogen content of limb muscles by $39 \%$ (Guy \& Snow, 1977). Fatigue during extended exercise partly results from a decline in blood glucose concentration, and the rate of this decline is affected by velocity, by the extent of glycogen stores, by dietary manipulation that spares glycogen mobilization and by training that promotes a greater use of both fat and glycogen during maximal exercise (Snow \& Mackenzie, 1977).

\section{POSTPRANDIAL FITNESS AND GLYCOGEN LOADING}

Glucose solutions given before prolonged exercise could increase glycogen degradation rate by raising plasma insulin thereby lowering FFA mobilization. Glucose given during hard exercise does not stimulate insulin secretion, but hyperinsulinaemia is protracted in TB following a meal (Stull et al. 1987; Frape, 1989); thus, timing of meals before extended exercise may be critical. Ponies given each day after exercise a fluid providing 5.4 MJ DE exhibited lower heart rates and blood lactate concentrations during and following subsequent exercise (Lindner et al. 1991).

Glycogen loading is the practice of elevating muscle glycogen by first depleting muscle glycogen, through hard anaerobic exercise, then repleting while the horse is at rest. Harris \& Hultman (1992) found no difference between diets in glycogen loading, but it probably occurs more effectively with a high-carbohydrate diet, than with a high-fat diet, following intense exercise that depletes type II muscle fibres of glycogen (Pagan et al. 1987a). Glycogen loading after aerobic work is ineffective and generally may cause poorer performance (Topliff et al. 1985, 1987; Pagan et al. 1987a) and an increased risk of exertional rhabdomyolysis (tying-up). Hodgson (1993) speculates that horses predisposed to tying-up exhibit a temporary failure in the control of intracellular $\mathrm{Ca}^{2+}$.

\section{DIETARY FAT: AND EXERCISE}

Carbohydrate-rich diets increase the risk of colic and laminitis, but fat-rich diets do not; whereas fats are not subject to microbial fermentation and they yield less $\mathrm{CO}_{2}$ per mol 


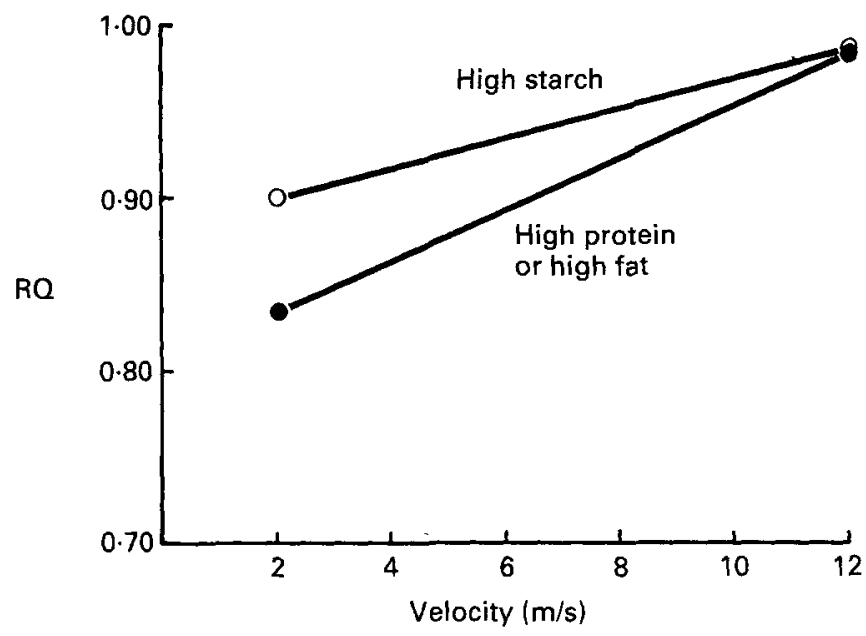

Fig. 1. Relationship of respiratory quotient (RQ) to velocity of horses given high-starch, high-protein or high-fat diets. At high velocity there is no difference in $R Q$ because high rate of energy expenditure demands glycolysis. At low-moderate velocity, fat and protein may be used.

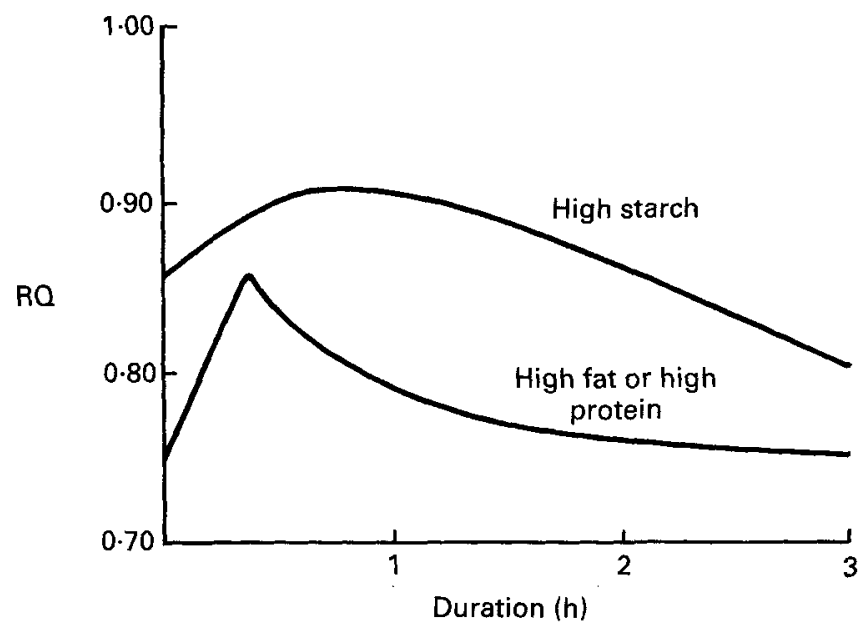

Fig. 2. Relationship between respiratory quotient (RQ) and time during aerobic work (low-moderate velocity, 4-6 m/s) in horses given high-starch, high-fat, or high-protein diets. On high-fat or high-protein diets fat mobilization becomes predominant earlier, thereby conserving muscle glycogen.

ATP generated. Dietary oils and fats are well utilized (McCann et al. 1987; Hollands \& Cuddeford, 1992; Potter et al. 1992b) and, as well as reducing the risk of colic and laminitis, they may promote intramuscular and hepatic fat metabolism. Hard training (Hambleton et al. 1980) and fat supplementation with anaerobic (Pagan et al. 1993) and extended aerobic (Pagan et al. 1987c) exercise are followed by an elevation in plasma FFA, but resting FFA are lowered by supplementation (Harkins et al. 1992). Thus, there may be stimulation of $\beta$-oxidation, or of both fat mobilization and metabolism (Figs. 1 and 2), sparing glycogen. Oils especially rich in polyunsaturated fatty acids (PUFA) have no notable benefit for ponies given a PUFA-deficient diet for 7 months (Sallmann et al. 
Table 1. Resting muscle glycogen as affected by added dietary fat ( $\mathrm{g} / \mathrm{kg}$ diet) in diets of differing energy densities but generally given to horses to equalize digestible energy (DE) intake*

\begin{tabular}{|c|c|c|c|c|c|c|c|}
\hline $\begin{array}{l}\text { Added dietary fat } \\
\text { (g/kg diet) } \ldots\end{array}$ & 0 & $20-30$ & $50-60$ & $80-100$ & $140-150$ & $\mathrm{SE}$ & \\
\hline Fat source & & & & & & & Source \\
\hline \multicolumn{8}{|c|}{ Muscle glycogen (mmol/kg wet tissue) } \\
\hline \multirow[t]{4}{*}{ Animal } & 81 & - & - & 78 & - & - & Hintz et al. (1978) \\
\hline & 94 & - & 109 & 143 & - & $10 \cdot 5$ & Meyers et al. (1989) \\
\hline & 88 & - & - & 127 & - & $2 \cdot 6$ & Oldham et al. (1990) \\
\hline & 93 & - & - & 145 & - & $2 \cdot 1$ & Scott et al. (1992) \\
\hline \multicolumn{8}{|c|}{ Muscle glycogen (mmol/kg dry matter) } \\
\hline \multirow[t]{2}{*}{ Vegetable oil $\dagger$} & - & 200 & 255 & 292 & 240 & - & Hambleton et al. (1980) \\
\hline & 680 & - & - & - & 580 & $100 \cdot 0$ & Pagan et al. $(1987 b)$ \\
\hline 市 & 198 & 229 & - & - & - & $12 \cdot 0$ & Harkins et al. (1992) \\
\hline
\end{tabular}

\footnotetext{
* Tissues were: gluteus medius, biceps femoris or quadriceps femoris.

$\uparrow$ Fat added replaced maize grain giving diets of different energy densities but constant daily energy and protein intakes.

¥ Fat added diet contained less roughage but more fat, starch and protein and was fed to provide equal DE intakes.
}

1992). Nevertheless, fatty acid chain length and degree of unsaturation may influence the exercise response (Pagan et al. 1993). The increased energy density achievable with dietary fat could be a necessary attribute (Worth et al. 1987). When fat amounting to 100 $\mathrm{g} / \mathrm{kg}$ diet replaced starch, heat production fell from $77 \%$ to $66 \%$ of DE and net energy (NE) rose from $16 \%$ to $36 \%$ of DE during work (Scott et al. 1993), reducing thermal stress (McCann et al. 1987).

Several reports indicate no difference in resting muscle glycogen concentration between high-starch and high-fat diets (Hintz et al. 1978; Pagan et al. 1987a; Topliff et al. 1987), whilst two other reports suggest that fat supplementation lowers muscle glycogen (Pagan et al. 1987b; Greiwe et al. 1989). Most reports describe increased resting muscle glycogen following inclusion of vegetable, or animal, fat at about $100 \mathrm{~g} / \mathrm{kg}$ diet to provide equal DE or metabolizable energy (ME) intakes (Hambleton et al. 1980; Meyers et al. 1987, 1989; Oldham et al. 1990; Harkins et al. 1992; Jones et al. 1992; Scott et al. 1992; Table 1). Effects of fat on hepatic glycogen capacity, which is $10 \%$ of that in skeletal muscle, are equivocal (Hambleton et al. 1980; Pagan et al. 1987b).

Respiratory quotient (RQ) rises with increasing speed (Pagan et al. 1987b), is lowered by training (Meyers et al. 1987) and is either not affected by dietary fat (Meyers et al. 1989), or is lowered by additional protein, or fat, during submaximal exercise (Pagan et al. 1987b) (Table 2, Figs. 1 and 2). RQ is positively correlated with muscle glycogen reserves during mild aerobic exercise and it declines as submaximal exercise progresses (Pagan et al. 1987b) (Fig. 2), indicating a sparing of glycogen. Higher stores of muscle glycogen achieved by fat supplementation accelerate mobilization of muscle glycogen during anaerobic exercise (Oldham et al. 1990; Jones et al. 1992; Scott et al. 1992). However, no clear picture emerges that fat would particularly benefit exercise in which 
Table 2. Relationship of supplementary dietary fat to respiratory quotient $(R Q)$ in horses exercised on treadmills

(Mean values with their standard errors)

\begin{tabular}{|c|c|c|c|c|c|c|c|c|}
\hline \multirow{2}{*}{$\begin{array}{c}\text { Speed } \\
(\mathrm{m} / \mathrm{min})\end{array}$} & \multirow[b]{2}{*}{ Slope $\left(^{\circ}\right)$} & \multirow{2}{*}{$\begin{array}{l}\text { Time } \\
\text { (min) }\end{array}$} & \multirow{2}{*}{$\begin{array}{l}\text { Added fat } \\
\text { ( } \mathrm{g} / \mathrm{kg} \text { diet) }\end{array}$} & \multicolumn{4}{|c|}{$\mathrm{RQ}$} & \multirow[b]{2}{*}{ Source } \\
\hline & & & & 0 & 50 & 100 & 150 & \\
\hline 180 & 9 & 20 & Mean & 0.910 & $0 \cdot 860$ & 0.870 & - & Meyers et al. (1989) \\
\hline \multirow[t]{2}{*}{300} & 0 & 90 & Mean & 0.830 & - & - & 0.750 & Pagan et al. (1987b) \\
\hline & & & SE & 0.012 & - & - & 0.022 & \\
\hline \multirow[t]{2}{*}{$360^{*}$} & 0 & 2 & Mean & 0.887 & - & - & 0.827 & \\
\hline & & & SE & 0.019 & - & - & 0.038 & \\
\hline \multirow[t]{2}{*}{$480^{*}$} & 0 & 2 & Mean & 0.890 & - & - & 0.873 & \\
\hline & & & $\mathrm{SE}$ & 0.031 & - & - & 0.030 & \\
\hline \multirow[t]{2}{*}{$600^{*}$} & 0 & 2 & Mean & 0.977 & - & - & 0.957 & \\
\hline & & & SE & 0.027 & - & - & 0.043 & \\
\hline
\end{tabular}

* Step-wise work test.

extended aerobic metabolism dominated (Hintz et al. 1978; Pagan et al. 1987b; Greiwe et al. 1989; Figs. 3 and 4). Metabolic adaptation to a high-fat diet may take 6-11 weeks (Custalow et al. 1993) and failure to take this, and other complications, into account may be responsible for some of the inconsistencies between different studies. Since fat yields energy only by oxidation, minimal glycogen sparing would be expected during maximal aerobic exertion. Some workers report similar (Worth et al. 1987), or lower (Meyers et al. 1989), blood glucose concentrations, in fat-supplemented horses during aerobic exercise; but most (Hintz et al. 1978; Hambleton et al. 1980; Webb et al. 1987a; Oldham et al. 1990; Harkins et al. 1992; Scott et al. 1992; Custalow et al. 1993) observed higher values during and after exercise of all types (Fig. 3, Table 3), even with increased work effort (Webb et al. 1987a; Harkins et al. 1992).

Lower heart rates, more rapid recovery of resting rates (Meyers et al. 1987), lower blood lactic acid concentrations during and after submaximal and strenuous exercise (Pagan et al. 1987a,c, 1993; Webb et al. 1987a; Meyers et al. 1989; Table 3), and higher lactate speed threshold (Custalow et al. 1993; Pagan et al. 1993) possibly reflect a slightly lower RQ (Fig. 1). The effects of high-protein diets on blood lactic acid may be more prominent than those of high-fat diets (Pagan et al. 1987a,c). Observations in human subjects indicate that high-protein high-fat diets increase the activity of skeletal muscle lipoprotein lipase ( $E C$ 3.1.1.34; LPL), whereas high-carbohydrate diets reduce that activity (Jacobs, 1981). Increased energy generation from fat oxidation with high-fat, high-protein diets may stem from the combined effects of increased muscle LPL hydrolysis of plasma triacylglycerols (TAG) and increased use of plasma FFA (Figs. 2 and 3), accounting for lower plasma lipids during aerobic standardized exercise test (Meyers et al. 1987). It is suggested that high-fat diets increase activity of muscle LPL (and possibly of TAG lipase), reducing adipose tissue LPL activity, in contrast to the effects of starch (Fig. 5). A dietary increase in either protein or fat normally results in decreased starch, reducing 'heating', anxiety, heart rate and excitability. The potential advantages and disadvantages of fat are proposed in Table 4.

Strenuous exercise causes increased plasma thiobarbituric acid-reacting substances (TBARS) and breath n-pentane per $\mathrm{kg}$ body weight (McMeniman \& Hintz, 1992). 


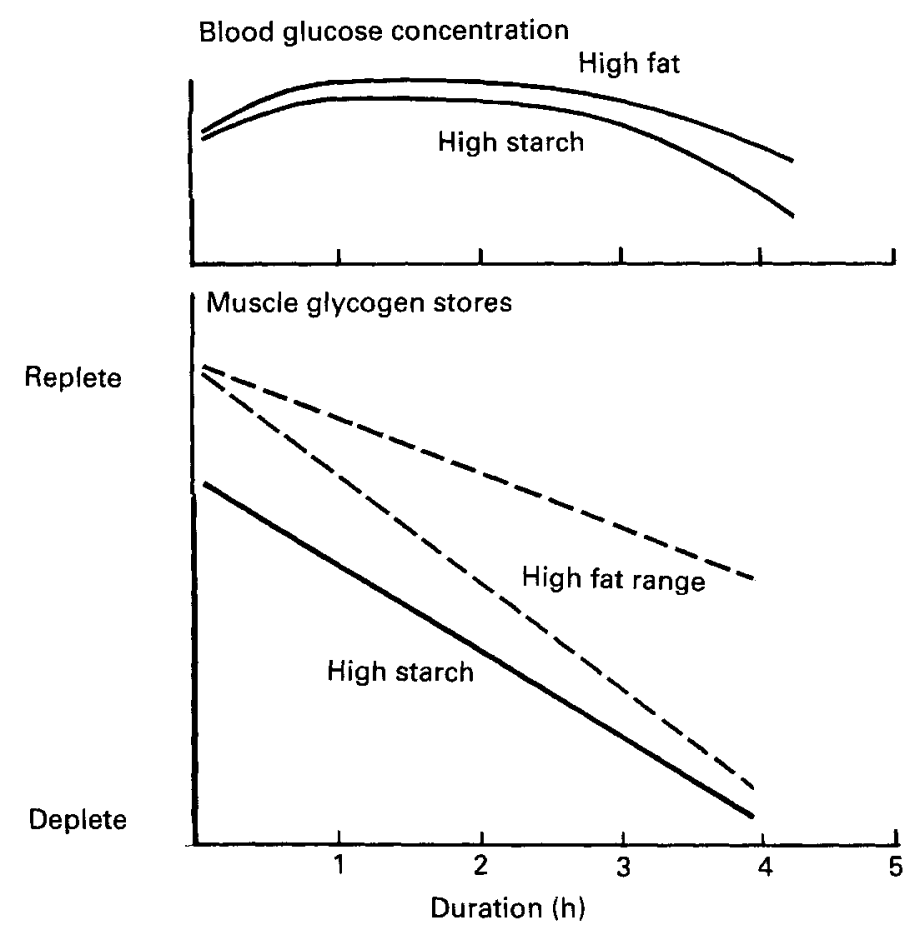

Fig. 3. Generalized relationships, with time, of blood glucose and muscle glycogen concentration in horses of moderate fatness during extended aerobic work.

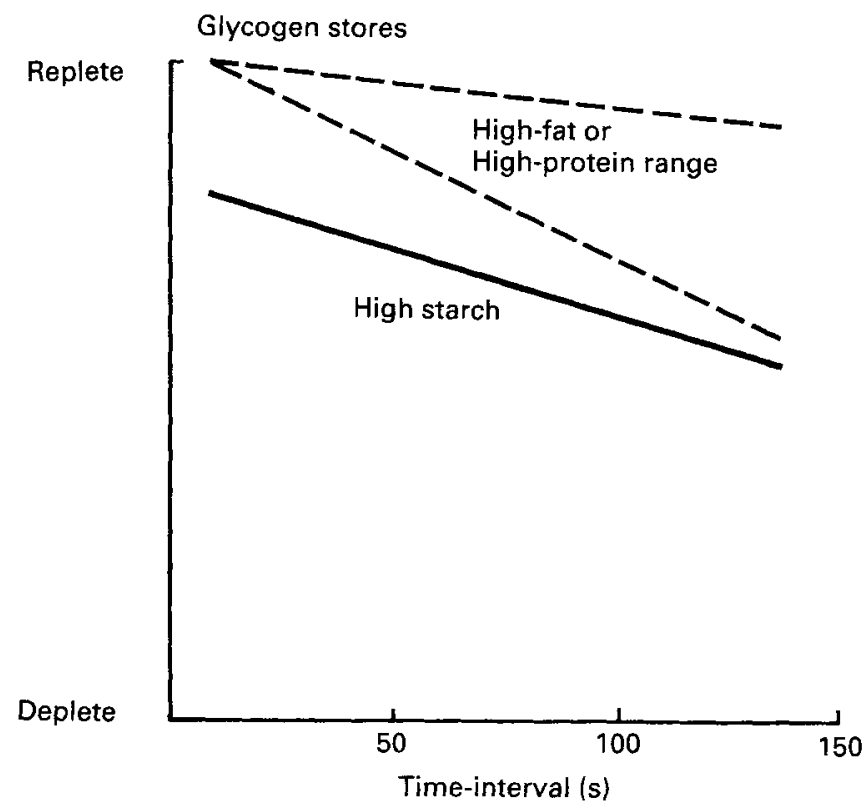

Fig. 4. Generalized relationship between glycogen stores and time-interval during intense anaerobic work $(>600 \mathrm{~m} / \mathrm{min},>190$ beats $/ \mathrm{min})$. 
Table 3. Effect of fat supplementation on blood plasma lactate and glucose concentrations during exercise at constant velocity $(C)$ or at uncontrolled velocity $(U C)$ and after postexercise rest

(Values averaged over the sources used for each comparison of carbohydrate control and added fat)

\begin{tabular}{|c|c|c|c|c|c|c|}
\hline \multirow{2}{*}{$\begin{array}{l}\text { Added dietary } \\
\text { fat }(\mathrm{g} / \mathrm{kg})\end{array}$} & \multirow[b]{2}{*}{ Velocity } & \multicolumn{2}{|c|}{$\begin{array}{l}\text { Plasma lactate } \\
\quad(\mathrm{mmol} / \mathrm{l})\end{array}$} & \multicolumn{2}{|c|}{$\begin{array}{l}\text { Plasma glucose } \\
\text { (mmol/l) }\end{array}$} & \multirow[b]{2}{*}{ Source } \\
\hline & & Work & Rest & Work & Rest & \\
\hline 0 & $\mathrm{C}$ & $2 \cdot 30$ & 1.98 & $5 \cdot 42$ & $5 \cdot 32$ & \multirow{2}{*}{$\begin{array}{l}\text { Hambleton et al. }(1980), \text { Meyers } \\
\text { et al. }(1987,1989), \text { Webb et al. } \\
(1987 a), \text { Worth et al. }(1987)\end{array}$} \\
\hline 100 & $\mathrm{C}$ & $1 \cdot 89$ & $1 \cdot 47$ & $4 \cdot 93$ & $5 \cdot 23$ & \\
\hline 0 & $\mathrm{C}$ & $9 \cdot 90$ & - & 2.52 & $3 \cdot 80$ & \multirow[t]{2}{*}{ Pagan et al. (1987c) } \\
\hline 100 & $\mathrm{C}$ & $6 \cdot 70$ & - & $2 \cdot 82$ & $3 \cdot 70$ & \\
\hline 0 & $\mathrm{UC}$ & $2 \cdot 31$ & $2 \cdot 25$ & $5 \cdot 32$ & 6.02 & \multirow{2}{*}{$\begin{array}{l}\text { Hintz et al. (1978), Harkins et al. } \\
\quad(1992)\end{array}$} \\
\hline 100 & $\mathrm{UC}$ & $2 \cdot 12$ & $2 \cdot 09$ & $6 \cdot 11$ & $6 \cdot 25$ & \\
\hline 0 & $\mathrm{UC}$ & $15 \cdot 79$ & $7 \cdot 30^{*}$ & 6.57 & $6 \cdot 55^{*}$ & \multirow{2}{*}{$\begin{array}{l}\text { Webb et al. }(1987 a), \text { Oldham } \\
\text { et al. }(1990), \text { Scott et al. }(1992)\end{array}$} \\
\hline 100 & UC & $18 \cdot 61$ & $14 \cdot 70^{*}$ & $7 \cdot 05$ & $7 \cdot 05^{*}$ & \\
\hline
\end{tabular}

* Data from Webb et al. (1987) only.

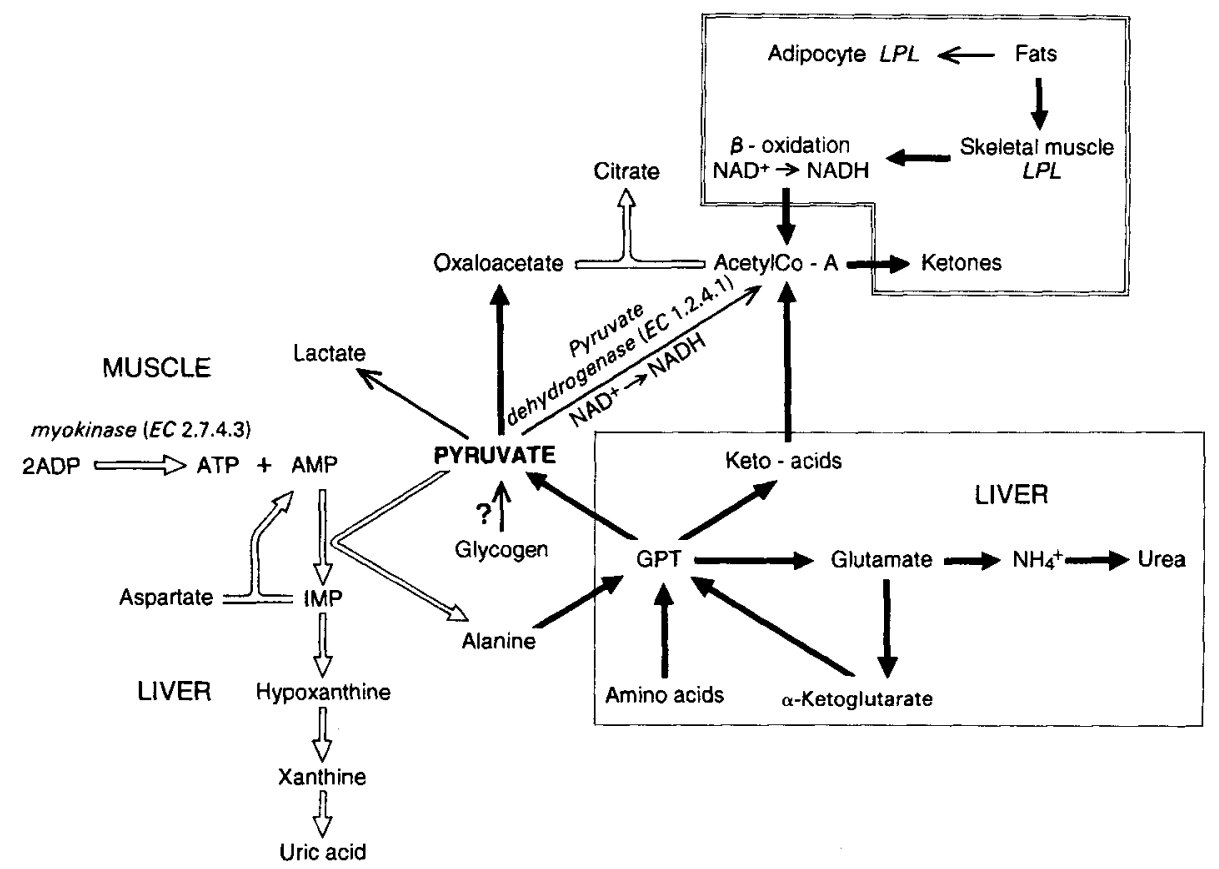

Fig. 5. Proposal for reactions stimulated $(\rightarrow)$, not measurably influenced $(\leftrightarrow)$, or suppressed $(\rightarrow)$ by high-protein or high-fat diets during equine exercise of moderate intensity in the postabsorptive state. Reactions proposed to be stimulated by dietary fat ( $\square$ ) and by dietary protein $(\square)$. GPT, glutamic-pyruvic transaminase ( $E C$ 2.6.1.2); LPL, lipoprotein lipase (EC 3.1.1.34); IMP, inosine monophosphate. 
Table 4. Provisional conclusions on effects of high-fat diets given to exercising horses compared with diets of normal fat concentration that provide similar amounts of dietary fibre, protein and digestible energy, but more starch

Advantages

1. Lower RQ during submaximal exercise (promoting fat catabolism) potentially extending endurance

2. Possible decrease in adipose tissue LPL activity and increase in muscle LPL activity

3. Increase in muscle glycogen stores, more glycolytic energy and possible delay in glycogen exhaustion during extended aerobic exercise

4. Increased, or sustained, blood glucose concentrations during extended exercise

5. Possibly delayed lactic acid accumulation during anaerobic exercise (lactic acid accumulation is proportional to the rate of glycogen expenditure, when other conditions are constant)

6. Reduction in heat of fermentation and in gut fill, which may benefit work at $>200$ bpm, but which may compromise endurance

7. Reduced excitability of hot blooded horses and a possible reduction in risks of colic and laminitis in all types of horse.

Disadvantages

1. High cost of high grade fat

2. Wide availability of poor-quality feed grade fat and difficulty of assessing quality

3. Lack of stability of large fat supplements in mixed feed and practical problems of administration to the horse

4. Refusal of high-fat diets, or delay in acceptance of equivalent intakes, i.e. lower palatability

5. Lower large intestinal fluid reserves for endurance events

$\mathrm{RQ}$, respiratory quotient; LPL, lipoprotein lipase (EC 3.1.1.34): bpm, beats/min.

However, the peroxidative stress of $30 \mathrm{~g}$ maize oil $/ \mathrm{kg}$ diet was accommodated in exercising ponies given $46.2 \mathrm{mg}$ vitamin $\mathrm{E} / \mathrm{kg}$ dietary dry matter, through increased plasma glutathione peroxidase $(E C$ 1.11.1.9) and superoxide dismutase $(E C$ 1.15.1.1) activities and ascorbic acid concentration, despite higher muscle TBARS regardless of vitamin E concentration.

\section{DIETARY PROTEIN REQUIREMENTS AND EXERCISE}

The National Research Council (1989) has concluded that dietary protein requirements of horses are proportional to those for DE. Both extended work (Rose et al. 1980) and exercise in the postabsorptive state following high-protein meals (Miller \& Lawrence, 1988) elevate plasma urea. Plasma $\mathrm{NH}_{3}$ and uric acid concentrations rise and attain maxima during recovery (Harris et al. 1987; Miller et al. 1987; Miller \& Lawrence, 1988), signifying an increased rate of AN cycling. A greater demand for ATP is partly met by the myokinase $(E C 2.7 .4 .3)$ reaction $(2 \mathrm{ADP} \rightarrow 1 \mathrm{ATP}+1 \mathrm{AMP}$; Fig. 5). Deamination of AMP, which supplementary $\mathrm{NaHCO}_{3}$ may ameliorate, produces $\mathrm{NH}_{3}$ and IMP, yielding uric acid (Harris et al. 1987). Additional dietary protein may, or may not, aggravate this.

Protein assimilation occurs during work, following rest (Meyer, 1987). Johnson et al. (1988) detected no increase in $\mathrm{N}$ balance of ponies when set to work. Patterson et al. (1985) found that $1.9 \mathrm{~g}$ digestible protein per $\mathrm{kg}$ body weight ${ }^{0.75}$ was adequate for intense exercise, although $\mathrm{N}$ balance was not determined. Orton et al. (1985) trotted growing horses for $12 \mathrm{~km}$ daily at $12 \mathrm{~km} / \mathrm{h}$, on either a $120-140 \mathrm{~g}$ protein $/ \mathrm{kg}$ diet or a $60-80 \mathrm{~g}$ protein $/ \mathrm{kg}$ diet; exercise increased feed intake of horses on the low-protein diet so that protein intake and growth rate equalled that of horses receiving the higher protein diet. 
In a survey of racing TB, Glade (1983) found that protein intake was positively correlated with time-period to finish, implying that excess protein depressed speed. There seems little justification for greatly increasing the daily protein intake of exercising horses to meet some putative increase in chronic requirement; the relationship of dietary protein with extreme performance is, however, far from clear. Despite seemingly high National Research Council (1989) estimates, actual intakes are still higher. Yet a $56 \%$ excess over the estimates amongst racing STB (Gallagher et al. 1992a) and 21\% excess for racing TB (Gallagher et al. 1992b) may reflect the natural protein content of palatable high-energy feeds.

Compared with horses given a control diet, $\mathrm{RQ}$ was lower in horses given a high-protein diet and exercised at high speed (Pagan et al. 1987b), implying stimulation of protein or fat metabolism in the postabsorptive state (Fig. 1), increasing urea yield (Frank et al. 1987) and water needs. Apart from this increased need Hintz et al. (1980) observed no detrimental protein effect in horses during distance riding, where dehydration causes fatigue. Compared with horses at about $\mathrm{N}$ balance, exercised horses with dietary protein intakes which give well in excess of $N$ balance exhibit increased concentrations of blood urea, but reduced postexercise venous blood $\mathrm{NH}_{3}$ when untrained. They also show decreased RQ during aerobic exercise and, when exercised at $240-600 \mathrm{~m} / \mathrm{min}$, heart rate, concentrations of blood and hepatic lactate and venous lactate:pyruvate are lower (Frank et al. 1987; Pagan et al. 1987b,c; Miller \& Lawrence, 1988; Miller-Graber et al. 1991). It is concluded that high-protein diets, above the need for $\mathrm{N}$ balance, may confer some metabolic advantages to working horses.

\section{PROTEIN DIGESTIBILITY OR DEGRADATION}

The true digestibility of protein in the small intestine of horses ranges from 45 to $80 \%$. At high rates of protein intake more will be degraded to $\mathrm{NH}_{3}$ in the large intestines. Utilization of $\mathrm{NH}_{3}$ by gut bacteria is between 80 and $100 \%$ (Potter et al. 1992c). Excessive protein intakes must inevitably increase the burden of unusable $\mathrm{N}$, either in the form of inorganic $\mathrm{N}$, or as relatively unusable bacterial protein. This burden is influenced by feeding sequence. The provision of a concentrate feed $2 \mathrm{~h}$ later than roughage, compared with simultaneous feeding, caused higher levels of plasma free, and particularly essential, amino acids, 6 and $9 \mathrm{~h}$ later (Cabrera et al. 1992). Plasma urea did not rise with dissociated feeding, but rose continuously for $9 \mathrm{~h}$ after the mixed feeding, indicating a large flow of $\mathrm{N}$ to the caecum. No corresponding measurements of heat production in the horse are available, but Belko et al. (1986) found that the thermic effect of food in exercising men increased with the protein content, 150-270 min postprandially.

\section{HEAT PRODUCTION, BLOOD FLOW AND MEAL TIME IN RELATION TO EXERCISE}

Blood volume is important for transport of both $\mathrm{O}_{2}$ and heat so that a large plasma volume is accompanied by a considerable skin blood flow. This volume can increase by $30 \%$ over 2 weeks training (Erickson et al. 1987). During exercise the rise in core temperature is proportional, not to exercise intensity, but to the percentage $V_{\mathrm{O}_{\text {mmax }}}$, which is increased by training. Most heat is dissipated through the skin, rather than the lungs, accompanied by an increased rate of insensible moisture and electrolyte losses. 
Table 5. Heat flow and blood redistribution as a consequence of eating and exercise

\begin{tabular}{|c|c|c|c|}
\hline Food intake leads to: & $\begin{array}{l}\uparrow \text { Coeliac blood flow } \\
\downarrow \text { Skeletal muscle blood flow, } \\
\uparrow \text { Cardiac work }\end{array}$ & Exercise leads to: & $\begin{array}{l}\uparrow \text { Skin blood flow } \\
\uparrow \text { Water-electrolyte loss } \\
\uparrow \text { Respiratory and heart rates } \\
\uparrow \text { Pulmonary blood flow }\end{array}$ \\
\hline
\end{tabular}

$\uparrow$, Increase; $\downarrow$, decrease.

Fatigue is delayed by partial replacement of these losses. Dilation of subcutaneous blood vessels during exercise diverts blood from skeletal muscles, contributing to a decrease in work capacity (Webb et al. 1987b). A diet supplemented with $10 \mathrm{~g}$ fat $/ \mathrm{kg}$ reduced the thermal load by increasing NE:DE (Potter et al. 1990; Scott et al. 1993). If circulatory adjustments fail to maintain heat balance, ventilation rate is increased, inducing respiratory alkalosis. Following feed ingestion the amount of blood distributed to the gastrointestinal (GI) tract increases, competing with the redistribution evoked by a rise in heat production. Accommodation is achieved by augmenting cardiac output, redistributing regional blood flow, or by combining these mechanisms (Table 5). Experiments with ponies (Duren et al. 1992) indicated that exercise of $7.8 \mathrm{~m} / \mathrm{s}$ on a $6.3^{\circ}$ incline at $75 \%$ of maximum heart rate for $30 \mathrm{~min}, 1.4 \mathrm{~h}$ after feeding, led to higher GI tract and skeletal muscle blood flows than those in fasted ponies and there was an increase in cardiac output, stroke volume and arterial blood pressure. Therefore, work is normally delayed for 5-8 h after feeding to avoid decreased blood glucose (Laurence et al. 1993) and problems of blood flow redistribution; the optimum time interval is influenced by the proportion of diet subject to fermentation.

\section{FEEDING BEFORE ENDURANCE EXERCISE}

Meyer (1987) concluded that endurance horses should be given large amounts of roughage $(6-8 \mathrm{~kg} / \mathrm{d})$ to dilate the large intestinal volume and increase water and electrolyte reserves. The maximum postprandial increase in caecal capacity is $8-14 \mathrm{~kg} / \mathrm{kg}$ dry matter ingested, depending on the fibre content, with $130-135 \mathrm{mmol} \mathrm{Na} / \mathrm{l}$ flow from the ileum. The average $\mathrm{Na}$ content of digesta in the large intestine is $40 \mathrm{mmol} / \mathrm{l}$. Meyer (1987) concluded from previous evidence (Meyer et al. 1982) that the horse should be fed more than $5 \mathrm{~h}$ before an endurance race, depending on the feeding sequence, as most of the residue will then have passed the ileo-caecal orifice. Meyer (1987) compared two rations, one contained $2 \mathrm{~kg}$ concentrates and $3 \mathrm{~kg}$ hay, providing $11.5 \mathrm{~g} \mathrm{Na}$ and $80 \mathrm{~g} \mathrm{~K}$, the other $2 \mathrm{~kg}$ oats, providing $1 \mathrm{~g} \mathrm{Na}$ and $10 \mathrm{~g} \mathrm{~K}$. At $4 \mathrm{~h}$ after feeding the retention of water, $\mathrm{Na}$ and $\mathrm{K}$ were respectively $5.8 \mathrm{~kg}, 9.3 \mathrm{~g}$ and $48 \mathrm{~g}$ for the first ration and $0.6 \mathrm{~kg}$, $0 \cdot 2 \mathrm{~g}$ and $1 \mathrm{~g}$ for the second ration. In support of Meyer (1987), Ralston (1988) found that horses failing to complete $160 \mathrm{~km}$ races had received mixtures containing less hay and more grain, and had been trained for greater distances ( $83 \mathrm{cf} .61 \mathrm{~km} /$ week). The energy intake per $\mathrm{km}$ of training was less in those that failed. Roughage has the disadvantage of inducing additional fluid weight and some contain excessive $\mathrm{K}$ that can stimulate diuresis, and loss of water. Water and electrolytes could be provided during a ride; but if there has been an iso-osmotic loss in sweat spontaneous drinking may not occur, unless the fall in plasma volume exceeds 6\% (Sufit et al. 1985). 


\section{ACID-BASE BALANCE AND EXERCISE}

Fatigue during exercise is associated with a deviation of blood $\mathrm{pH}$ from the ideal range, causing metabolic acidosis, or with over-heating, respiratory alkalosis. In lactic acidosis there is increased production of $\mathrm{H}^{+}$ions, owing to an $\mathrm{O}_{2}$ debt. With overheating there is increased loss of $\mathrm{CO}_{2}$, resulting from a high respiration volume per min. Mineral nutrition has a role in acid-base balance. Excess base (or acid) in feed may be approximated as the difference between the sums of mineral cations and anions:

$$
\text { base excess }(\mathrm{MEQ} / \mathrm{g})=(\mathrm{Na}+\mathrm{K}+\mathrm{Ca}+\mathrm{Mg})-(\mathrm{Cl}+\mathrm{P}+\mathrm{S}) \text {. }
$$

Despite dietary variations in these, adapation serves to maintain the $\mathrm{pH}$ of body fluids in the normal physiological range. Tissue $\mathrm{pH}$ may be altered to the extent that these compensatory mechanisms are not fully effective. Excretion of excess fixed ions requires water as a solvent, increasing water demand. Loading the horse with electrolytes temporarily increases accumulation of electrolytes and water in the large intestine (Slade, 1987) which may act as a reserve for extended work (Coenen, 1992; Meyer, 1992). The daily ileo-caecal flow of water and electrolytes per $\mathrm{kg}$ body weight is in the range of $100-140 \mathrm{ml}$ water, $300-420 \mathrm{mg} \mathrm{Na}{ }^{+}, 50-70 \mathrm{mg} \mathrm{K}^{+}$and $100-140 \mathrm{mg} \mathrm{Cl}^{-}$. Absorption along with water from the large intestine, during ingesta fermentation, is about $75-95 \%$ for $\mathrm{Na}^{+}$, over $90 \%$ for $\mathrm{Cl}^{-}$and $30-55 \%$ for $\mathrm{K}^{+}$(Meyer, 1992). These nutrients can revive tissue depleted of water, $\mathrm{Cl}^{-}, \mathrm{Na}^{+}, \mathrm{K}^{+}$and $\mathrm{Ca}^{2+}$ through sweating (Rose et al. 1977), especially in horses that are severely dehydrated (Carlson et al. 1976) and are reluctant to drink.

High base excess in the diet (greater than $200 \mathrm{mg} / \mathrm{kg}$ ) produces beneficial effects on $\mathrm{pH}, \mathrm{pCO}_{2}$ and $\mathrm{HCO}_{3}{ }^{-}$concentration of blood and on recovery of normal blood glucose (Stutz et al. 1992) and heart rate (Popplewell et al. 1993) after exercise. The benefit from transitory buffering appears to be achieved by feeding $3.5-4.5 \mathrm{~h}$ before anaerobic exercise.

Anaerobic exercise causes a rise in plasma $\mathrm{K}^{+}$released from the contracting muscle fibre. If there is inadequate buffering within active muscle fibres, ATP may be less available and the $\mathrm{Na}-\mathrm{K}$ pump will be inhibited, leading to poor re-uptake of $\mathrm{K}^{+}$(Harris \& Snow, 1988, 1992). The loss of intracellular $\mathrm{K}^{+}$leads to an altered transmembrane potential that may contribute to fatigue during exercise. Oral $\mathrm{NaHCO}_{3}$ reduces the rise in plasma $\mathrm{NH}_{3}$ by reducing deamination of AMP and possibly by accelerating $\mathrm{H}^{+}$ removal (Greenhaff et al. 1990a, 1991). A positive effect of oral $\mathrm{NaHCO}_{3}$ on performance seems to occur only during exercise of 2-3 min (Lawrence et al. 1987, 1990; Harkins \& Kamerling, 1992). The optimum dose and time is about $0.4 \mathrm{~g} \mathrm{NaHCO}_{3} / \mathrm{kg}$ body weight (in 1 litre water), 2-4 h before work (Greenhaff et al. 1990b; Corn et al. 1993). However, a dose of $\mathrm{Na}$ equivalent to $20 \%$ of the body's total exchangeable $\mathrm{Na}$ should increase plasma volume and could have an effect on sprint performance contrary to that expected of a buffer. Moreover, the value of the large intestine as a reservoir of $\mathrm{Na}$ may be modulated by acetate production (Argenzio et al. 1977), which varies with the timing and nature of the last meal. When supplemental $\mathrm{NaHCO}_{3}$ and $\mathrm{NaCl}(1 \mathrm{~g} / \mathrm{kg}$ body weight $)$ were compared, the $\mathrm{NaHCO}_{3}$ extended exercise to exhaustion on a treadmill and increased blood lactate, but compared with untreated horses gave poorer endurance, possibly from a higher fluid load (Lloyd et al. 1993). The response to oral $\mathrm{NaHCO}_{3}$ is complicated, as alkalosis caused by the $1 \mathrm{~g} / \mathrm{kg}$ dose led to hypercapnia and some hypoxaemia through respiratory compensation. Thus, the dose, method of administration and overall effects of $\mathrm{NaHCO}_{3}$ and water will bear further examination. 
A more enlightened approach to combating the rise in intracellular $\mathrm{H}^{+}$may be to alter the intracellular concentration of the imidazole dipeptide buffers carnosine ( $\beta$-alanylhistidine) and its $\mathrm{N}^{2}$-methyl derivative, anserine. Carnosine contributes $30 \%$ of the buffering in equine skeletal muscle (Harris et al. 1991a), and in type IIB fibres (prominent in equine muscle) it may account for up to $50 \%$, with a concentration of 188 $\mathrm{mmol} / \mathrm{kg}$ muscle dry matter (Sewell et al. 1991a,b, 1992b).

\section{DIETARY ADDITIVES}

$\mathrm{Si}$ is a component of bone structure. Sodium zeolite at $18.6 \mathrm{~g} / \mathrm{kg}$ total diet given to 6-month-old foals for 12 months increased plasma Si and speed and extended work time before leg injury after 18 months of age (Nielsen et al. 1993; Reynolds et al. 1993). Fatigue caused by lactic acid accumulation has been countered by the dietary inclusion of $\mathrm{N}, \mathrm{N}$-dimethylglycine (DMG) as a 'metabolic enhancer'. Mature, conditioned, exercised horses supplemented with $1.6 \mathrm{mg}$ DMG per $\mathrm{kg}$ body weight failed to show typical increases in blood lactic acid concentration (Moffitt et al. 1985).

$\mathrm{L}$-Carnitine ( $\beta$-hydroxy- $\gamma$-trimethylaminobutyric acid) is a conditionally essential nutrient, which is present in substantial amounts in diets composed of animal products, but low in feed sources derived from plants. Carnitine facilitates the transport of long-chain fatty acids across inner mitochondrial membranes and it may regulate acetyl-CoA:CoA, by buffering excess acetyl units during intense exercise (Carlin et al. 1990). Supplements of $10 \mathrm{~g} \mathrm{~L}$-carnitine twice daily for 2 months have doubled plasma carnitine concentration of TB (Snow \& Harris, 1989), but there was neither increased content in, nor loss of total carnitine from, middle gluteal muscle, associated with intense exercise (Foster et al. 1988; Foster \& Harris, 1989, 1992). The effect of fat on the need for carnitine has not been examined and it is questionable whether the function of carnitine can be enhanced, except in those individuals that have low biosynthetic ability.

\section{FAT-SOLUBLE VITAMINS AND EXERCISE}

Schubert $(1990,1991)$ assessed the response of 247 TB to large supplements of vitamin E. Improved performance (significantly more wins and places than controls) was obtained when $1.0 \mathrm{~g} \alpha$-tocopherol was added to a daily ration providing $0.2 \mathrm{~g}$ vitamin $\mathrm{E}$. Large doses, of this order, are known to increase muscle $\alpha$-tocopherol (Ronéus et al. 1986). Yet McMeniman \& Hintz (1992) held ponies on a diet containing $46 \mathrm{mg}$ vitamin $\mathrm{E} / \mathrm{kg}$ dry matter for 10 months but muscle vitamin $\mathrm{E}$ concentration remained at $8-10$ $\mu \mathrm{g} / \mathrm{g}$. Exhaustive treadmill exercise which led to plasma lactic acid concentrations of 14 $\mathrm{mmol} / 1$, caused heart rates in excess of $180 \mathrm{bpm}$ and increased plasma TBARS, evoked no increase in exercise fitness with additional vitamin $E$. Nevertheless, both pre- and postexercise plasma vitamin $E$ concentrations were negatively correlated with the corresponding plasma TBARS concentration. Vitamin E supplementation (Ji et al. 1990) had little effect on erythrocytes other than to increase glutathione peroxidase activity 30 min after exercise that caused an 18 -fold increase in blood lactate.

\section{WATER-SOLUBLE VITAMINS, TRACE ELEMENTS AND EXERCISE}

Boitin is the only water-soluble vitamin observed to give clinical responses with normal diets. Weak misshapen and crumbly hooves respond to supplementation (Comben et al. 
1984). A greater response has occurred with $15 \mathrm{mg} /$ horse than with $7.5 \mathrm{mg} /$ horse daily (Buffa et al. 1992). These amounts are considerably higher than should normally be adequate. No evidence is available that either dietary ascorbic acid or abnormal amounts of trace elements will improve performance.

\section{CONCLUSIONS}

Differences between cereal types and processing methods influence glucose:VFA in products of digestion and fermentation and, therefore, the fluid content of the hindgut. These effects are likely to influence performance.

Factors influencing the optimum form, feeding sequence and timing of a meal before exercise include: fluid content and weight of ingesta, fluid and electrolyte reserve in the large intestine, glycaemia, amino acidaemia and insulinaemia, blood distribution and cardiac work.

High-fat (higher energy density) and high-protein diets both may benefit anaerobic and aerobic performance. Muscle glycogen stores, RQ, blood glucose and lactic acid concentrations are influenced and thermal load is decreased by fat supplements. Mechanisms are discussed.

A high dietary base excess, and $\mathrm{NaHCO}_{3}$ given at a rate of $0.4 \mathrm{~g} / \mathrm{kg}$ body weight $2-4 \mathrm{~h}$ before a 2-3 min sprint, may improve performance; however, larger doses of $\mathrm{HCO}_{3}$ may expand plasma volume to the detriment of sprint speed, changing tidal volume. A dietary base excess up to $300 \mathrm{meq} / \mathrm{kg}$ dry matter, with limited water access, could ameliorate fatigue in sprint events.

The author would like to thank Dr Roger Harris and Ms Catherine Orme, of the Animal Health Trust Newmarket, for useful discussions on the subject.

\section{REFERENCES}

Argenzio, R. A., Southworth, M., Lowe, J. E. \& Stevens, C. E. (1977). Interrelationship of $\mathrm{NaHCO}_{3}$ and volatile fatty acid transport by equine large intestine. American Journal of Physiology 233, E469-E478.

Belko, A., Z., Barbieri, T. F. \& Wong, E. C. (1986). Effect of energy and protein intake and exercise intensity on the thermic effect of food. American Journal of Clinical Nutrition 43, 863-869.

Buffa, E. A., Van Den Berg, S. S., Verstraete, F. J. M. \& Swart, N. G. N. (1992). Effect of dietary biotin supplement on equine hoof horn growth rate and hardness. Equine Veterinary Journal 24, 472-474.

Cabrera, L., Julliand, V., Faurie, F. \& Tisserand, J. L. (1992). Influence of feeding roughage and concentrate (soy bean meal) simultaneously or consecutively on levels of plasma free amino acids and plasma urea in the equine. 1. Europäische Konferenz über die Ernährung des Pferdes, pp. 144-149. Hannover: Tierärzliche Hochschule Hannover.

Carlin, J. I., Harris, R. C., Cederblad, G., Constantin-Teodosiu, D., Snow, D. H. \& Hultman, E. (1990). Association between muscle acetyl-CoA and acetylcarnitine levels in the exercising horse. Journal of Applied Physiology 69, 42-45.

Carlson, G. P., Ocen, P. O. \& Harrold, D. (1976). Clinicopathologic alterations in normal and exhausted endurance horses. Theriogenology 6, 93-104.

Coenen, M. (1992). Chloridkonzentrationen und-mengen im verdauungskanal des Pferdes (Chloride in the gastrointestinal tract of the horse). 1. Europäische Konferenz über die Ernährung des Pferdes, pp. 73-76. Hannover: Tierärzliche Hochschule Hannover.

Comben, N., Clark, R. J. \& Sutherland, D. J. B. (1984). Clinical observations on the response of equine hoof defects to dietary supplementation with biotin. Veterinary Record 115, 642-645.

Corn, C. D., Potter, G. D. \& Odom, T. W. (1993). Blood buffering in sedentary miniature horses after administration of sodium bicarbonate in single doses of varying amounts. Proceedings of the Thirteenth Equine Nutrition and Physiology Symposium no. 504, pp. 108-112. Champaign, 111.: American Society of Animal Science. 
Custalow, S. E., Ferrante, P. L., Taylor, L. E., Moll, H. D., Meacham, T. N., Kronfeld, D. S. \& Tiegs, W. (1993). Lactate and glucose responses to exercise in the horse are affected by training and dietary fat. Proceedings of the Thirteenth Equine Nutrition and Physiology Symposium no. 504, pp. 179-184. Champaign, Ill.: American Society of Animal Science.

Duren, S. E., Manohar, M., Sikkes, B., Jackson, S. \& Baker, J. (1992). Influence of feeding and exercise on the distribution of intestinal and muscle blood flow in ponies. 1. Europäische Konferenz über die Ernährung des Pferdes, pp. 24-28. Hannover: Tierärzliche Hochschule Hannover.

Erickson, H. H., Erickson, B. K., Landgren, G. L., Hopper, M. K., Butler, H. C. \& Gillespie, J. R. (1987). Physiological characteristics of a champion endurance horse. Proceedings of the Tenth Equine Nutrition and Physiology Symposium, pp. 493-498. Champaign, Ill.: American Society of Animal Science.

Foster, C. V. L. \& Harris, R. C. (1989). Plasma carnitine concentrations in the horse following oral supplementation using a triple dose regime. Equine Veterinary Journal 21, 376-377.

Foster, C. V. L. \& Harris, R. C. (1992). Total carnitine content of the middle gluteal muscle of Thoroughbred horses: normal values, variability and effect of acute exercise. Equine Veterinary Journal 24, 52-57.

Foster, C. V. L., Harris, R. C. \& Snow, D. H. (1988). The effect of oral L-carnitine supplementation on the muscle and plasma concentrations in the thoroughbred horse. Comparative Biochemistry and Physiology 91A, 827-835.

Frank, N. B., Meacham, T. N. \& Fontenot, J. P. (1987). Effect of feeding two levels of protein on performance and nutrition of exercising horses. Proceedings of the Tenth Equine Nutrition and Physiology Symposium, pp. 579-583. Champaign, Ill.: American Society of Animal Science.

Frape, D. L. (1988). Dietary requirements and athletic performance of horses. Equine Veterinary Journal 20, $163-172$.

Frape, D. L. (1989). Nutrition and the growth and racing performance of thoroughbred horses. Proceedings of the Nutrition Society 48, 141-152.

Gallagher, K., Leech, J. \& Stowe, H. (1992a). Protein energy and dry matter consumption by racing Standardbreds: a field survey. Journal of Equine Veterinary Science 12, 382-388.

Gallagher, K., Leech, J. \& Stowe, H. (1992b). Protein energy and dry matter consumption by racing Thoroughbreds: a field survey. Journal of Equine Veterinary Science 12, 43-48.

Glade, M. J. (1983). Nutrition and performance of racing thoroughbreds. Equine Veterinary Journal 15, 31-36.

Greenhaff, P. L., Harris, R. C. \& Snow, D. H. (1990a). The effect of sodium bicarbonate $\left(\mathrm{NaHCO}_{3}\right)$ administration upon exercise metabolism in the thoroughbred horse. Journal of Physiology 420, 69P.

Greenhaff, P. L., Harris, R. C., Snow, D. H., Sewell, D. A. \& Dunnett, M. (1991). The influence of metabolic alkalosis upon exercise metabolism in the thoroughbred horse. European Journal of Applied Physiology 63, 129-134.

Greenhaff, P. L., Snow, D. H., Harris, R. C. \& Roberts, C. A. (1990b). Bicarbonate loading in the Thoroughbred: dose, method of administration and acid-base changes. Equine Veterinary Journal 9. Suppl., 83-85.

Greiwe, K. M., Meacham, T. N., Fregin, G. F. \& Walberg, J. L. (1989). Effect of added dietary fat on exercising horses. Proceedings of the Eleventh Equine Nutrition and Physiology Symposium, pp. 101-106. Champaign, Ill.: American Society of Animal Science.

Guy, P. S. \& Snow, D. H. (1977). The effect of training and detraining on muscle composition in the horse. Journal of Physiology 269, 33-51.

Hambleton, P. L., Slade, L. M., Hamar, D. W., Kienholz, E. W. \& Lewis, L. D. (1980). Dietary fat and exercise conditioning effect on metabolic parameters in the horse. Journal of Animal Science 51, 1330-1339.

Harkins, J. D. \& Kamerling, S. G. (1992). Effects of induced alkalosis on performance in thoroughbreds during a 1,600-m race. Equine Veterinary Journal 24, 94-98.

Harkins, J. D., Morris, G. S., Tulley, R. T., Nelson, A. G. \& Kamerling, S. G. (1992). Effect of added dietary fat on racing performance in thoroughbred horses. Journal of Equine Veterinary Science 12, 123-129.

Harris, P. \& Snow, D. H. (1988). The effects of high intensity exercise on the plasma concentration of lactate, potassium and other electrolytes. Equine Veterinary Journal 20, 109-113.

Harris, P. \& Snow, D. H. (1992). Plasma potassium and lactate concentrations in thoroughbred horses during exercise of varying intensity. Equine Veterinary Journal 24, 220-225.

Harris, R. C., Dunnett, M. \& Snow, D. H. (1991a). Muscle carnosine content is unchanged during maximal intermittent exercise. Equine Exercise Physiology 3, 257-261.

Harris, R. C. \& Hultman, E. (1992). Nutritional strategies for enhanced performance in the racing camel: lessons learned from man and horse. Proceedings of the First International Camel Conference, pp. 243-246. Newmarket: R \& W Publications (Newmarket) Ltd. 
Harris, R. C., Marlin, D. J. \& Snow, D. H. (1987). Metabolic response to maximal exercise of 800 and $2,000 \mathrm{~m}$ in the thoroughbred horse. Journal of Applied Physiology 63, 12-19.

Harris, R. C., Marlin, D. J. \& Snow, D. H. (1991b). Lactate kinetics, plasma ammonia and performance following repeated bouts of maximal exercise. Equine Exercise Physiology 3, 173-178.

Harris, R. C., Marlin, D. J., Snow, D. H. \& Harkness, R. A. (1991c). Muscle ATP loss and lactate accumulation at different work intensities in the exercising Thoroughbred horse. European Journal of Applied Physiology 62, 235-244.

Harris, R. C., Söderlund, K. \& Hultman, E. (1992). Elevation of creatine in resting and exercised muscle of normal subjects by creatine supplementation. Clinical Science 83, 367-374.

Hintz, H. F., Ross, M. W., Lesser, F. R., Leids, P. F., White, K. K., Lowe, J. E., Short, C. E. \& Schryver, H. F. (1978). The value of dietary fat for working horses. I. Biochemical and Hematological Evaluations 2 , $483-488$.

Hintz, H. F., White, K., Short, C., Lowe, J. \& Ross, M. (1980). Effects of protein levels on endurance horses. Journal of Animal Science 51, Suppl., 202-203.

Hodgson, D. R. (1993). Exercise-associated myopathy: is calcium the culprit? Equine Veterinary Journal 25, $1-3$.

Hollands, T. \& Cuddeford, D. (1992). Effect of supplementary soya oil on the digestibility of nutrients contained in a 40:60 roughage/concentrate diet fed to horses. 1. Europäische Konferenz über die Ernährung des Pferdes, pp. 128-132. Hannover: Tierärzliche Hochschule Hannover.

INRA (1990). L'alimentation des Chevaux, p. 232 [W. Martin-Rosset, editor]. Versailles: INRA Publications.

Jacobs, I. (1981). Lactate, muscle glycogen and exercise performance in man. Acta Physiologica Scandinavica, Suppl., 495, 3-35.

Ji, L. L., Dillon, D. A., Bump, K. D. \& Lawrence, L. M. (1990). Antioxidant enzymes response to exercise in equine erythrocytes. Journal of Equine Veterinary Science 10, 380-383.

Johnson, K. A., Sigler, D. H. \& Gibbs, P. G. (1988). Nitrogen utilization and metabolic responses of ponies to intense anaerobic exercise. Journal of Equine Veterinary Science 8, 249-254.

Jones, D. L., Potter, G. D., Greene, L. W. \& Odom, T. W. (1992). Muscle glycogen in exercised miniature horses at various body conditions and fed a control or fat supplemented diet. Journal of Equine Veterinary Science 12, 287-291.

Kienzle, E., Radicke, S., Wilke, S., Landes, E. \& Meyer, H. (1992). Praeileale Stärkeverdauung in Abhängigkeit von Stärkeart und -zubereitung (Pre-ileal starch digestion in relation to source and preparation of starch). 1. Europäische Konferenz über die Ernährung des Pferdes, pp. 103-106. Hannover: Tierärzliche Hochschule Hannover.

Lawrence, L., Kline, K., Miller, P., Smith, J., Siegel, A., Kurcz, E., Kane, R., Fisher, M. \& Bump, K. (1987). Effect of sodium bicarbonate on racing Standardbreds. Proceedings of Tenth Equine Nutrition and Physiology Symposium, pp. 499-503. Champaign, Ill: American Society of Animal Science.

Lawrence, L., Kline, K., Miller-Graber, P., Siegel, A., Kurca, K., Fisher, M. \& Bump, K. (1990). Effect of sodium bicarbonate on racing Standardbreds. Journal of Animal Science 68, 673-677.

Lawrence, L., Soderholm, L. V., Roberts, A., Williams, J. \& Hintz, H. (1993). Feeding status affects glucose metabolism in exercising horses. Journal of Nutrition 123, 2152-2157.

Lindner, A., Wittke, P. von, Bendig, M. \& Sommer, H. (1991). Effect of an energy enriched electrolyte fluid concentrate on heart rate and lactate concentration of ponies during and after exercise. Proceedings of the Twelfth Equine Nutrition and Physiology Symposium, pp. 93-94. Champaign, Ill.: American Society of Animal Science.

Lloyd, D. R., Evans, D. L., Hodgson, D. R., Suann, C. J. \& Rose, R. J. (1993). Effects of sodium bicarbonate on cardiorespiratory measurements and exercise capacity in Thoroughbred horses. Equine Veterinary Journal 25, 125-129.

McCann, J. S., Meacham, T. N. \& Fontenot, J. P. (1987). Energy utilization and blood traits of ponies fed fat-supplemented diets. Journal of Animal Science 65, 1019-1026.

McMeniman, N. P. \& Hintz, H. F. (1992). Effect of vitamin E status on lipid peroxidation in exercised horses. Equine Veterinary Journal 24, 482-484.

Meyer, H. (1987). Nutrition of the equine athlete. In Equine Exercise Physiology, vol. 2, pp. 644-673 [J. R. Gillespie and N. E. Robinson, editors]. Davis, CA: ICEEP Publications.

Meyer, H. (1992). Intestinaler Wasser- und Elektrolytstoffwechsel Pferdes (Intestinal water and electrolyte metabolism in horses). 1. Europäische Konferenz über die Ernährung des Pferdes, pp. 67-72. Hannover: Tierärzliche Hochschule Hannover. 
Meyer, H., Lindemann, G. \& Schmidt, M. (1982). Einfluss unterschiedlicher Mischfuttergaben pro Mahlzeit auf praecaecale- und postileale Verdauungsvorgänge beim Pferd (Influence of variable amounts of mixed feed given each meal on precaecal and pre-ileal digestion in the horse). Journal of Animal Physiology and Animal Nutrition 13, Suppl., 32-39.

Meyers, M. C., Potter, G. D. Evans, J. W., Greene, L. W. \& Crouse, S. F. (1989). Physiological and metabolic response of exercising horses to added dietary fat. Journal of Equine Veterinary Science 9, 218-223.

Meyers, M. C., Potter, G. D., Greene, L. W., Crouse, S. F. \& Evans, J. W. (1987). Physiological and metabolic response of exercising horses to added dietary fat. Proceedings of the Tenth Equine Nutrition and Physiology Symposium, pp. 107-113. Champaign, Ill.: American Society of Animal Science.

Miller, P. A. \& Lawrence, L. M. (1988). The effect of dietary protein level on exercising horses. Journal of Animal Science 66, 2185-2192.

Miller, P. A., Lawrence, L. M., Kline, K., Kane, R., Kurcz, E., Smith, J., Fisher, M., Siegel, A. \& Bump, K. (1987). Plasma ammonia and other metabolites in the racing Standardbred. Proceedings of the Tenth Equine Nutrition and Psysiology Symposium, pp. 397-402. Champaign, Ill.: American Society of Animal Science.

Miller-Graber, P. A., Lawrence, L. M., Foreman, J. H., Bump, K. D., Fisher, M. G. \& Kurcz, E. V. (1991). Dietary protein level and energy metabolism during treadmill exercise in horses. Journal of Nutrition 121, 1462-1469.

Moffitt, P. G., Potter, G. D., Kreider, J. L. \& Moritani, T. M. (1985). Venous lactic acid levels in exercising horses fed N,N-dimethylglycine. Proceedings of the Ninth Equine Nutrition and Physiology Symposium, pp. 248-253. Champaign, Ill.: American Society of Animal Science.

National Research Council (1989). Nutrient Requirements of Horses, 5th revised edn. Washington, DC: National Academy of Sciences.

Nielsen, B. D., Potter, G. D., Morris, E. L., Odom, T. W., Senor, D. M., Reynolds, J. A., Smith, W. B., Martin, M. T. \& Bird, E. H. (1993). Training distance to failure in young racing Quarter Horses fed sodium zeolite A. Proceedings of the Thirteenth Equine Nutrition and Physiology Symposium no. 504, pp. 5-10. Champaign, Ill.: American Society of Animal Science.

Oldham, S. L., Potter, G. D., Evans, J. W., Smith, S. B., Taylor, T. S. \& Barnes, W. (1990). Storage and mobilization of muscle glycogen in exercising horses fed a fat-supplemented diet. Journal of Equine Veterinary Science 10, 353-359.

Orton, R. K., Hume, I. D. \& Leng, R. A. (1985). Effects of level of dietary protein and exercise on growth rates of horses. Equine Veterinary Journal 17, 381-385.

Pagan, J. D., Essen-Gustavsson, B., Lindholm, A. \& Thornton, J. (1987a). The effect of exercise and diet on muscle and liver glycogen repletion in Standardbred horses. Proceedings of the Tenth Equine Nutrition and Physiology Symposium, pp. 431-436. Champaign, Ill.: American Society of Animal Science.

Pagan, J. D., Essen-Gustavsson, B., Lindholm, A. \& Thornton, J. (1987b). The effect of dietary energy source on exercise performance in Standardbred horses. In Equine Excercise Physiology, vol. 2, pp. 686-700. Cambridge: Granta Editions.

Pagan, J. D., Essen-Gustavsson, B., Lindholm, A. \& Thornton, J. (1987c). The effect of dietary energy source on blood metabolites in Standardbred horses during exercise. Proceedings of the Tenth Equine Nutrition and Physiology Symposium, pp. 425-430. Champaign, Ill.: American Society of Animal Science.

Pagan, J. D., Tiegs, W., Jackson, S. G. \& Murphy, H. Q. (1993). The effect of different fat sources on exercise performance in thoroughbred racehorses. Proceedings of the Thirteenth Equine Nutrition and Physiology Symposium no. 504, pp. 125-129. Champaign, Ill.: American Society of Animal Science.

Patterson, P. H., Coon, C. N. \& Hughes, I. M. (1985). Protein requirements of mature working horses. Journal of Animal Science 61, 187-196.

Plummer, C., Knight, P. K., Ray, S. P. \& Rose, R. J. (1991). Cardiorespiratory and metabolic effects of propranolol during maximal exercise. In Equine Exercise Physiology, vol. 3, pp. 465-474 [S. G. B. Persson, A. Lindholm and L. Jeffcott, editors]. Davis, CA: ICEEP Publications.

Popplewell, J. C., Topliff, D. R., Freeman, D. W. \& Breazile, J. E. (1993). Effects of dietary cation-anion balance on acid-base balance and blood parameters in anaerobically exercised horses. Proceedings of the Thirteenth Equine Nutrition and Physiology Symposium, pp. 191-196. Champaign, Ill.: American Society of Animal Science.

Potter, G. D., Arnold, F. F., Householder, D. D., Hansen, D. H. \& Brown, K. M. (1992a). Digestion of starch in the small or large intestine of the equine. 1. Europäische Konferenz über die Emährung des Pferdes, pp. 107-111. Hannover: Tierärzliche Hochschule Hannover. 
Potter, G. D., Gibbs, P. G., Haley, R. G. \& Klendshoj, C. (1992c). Digestion of protein in the large intestines of equines fed mixed diets. 1. Europäische Konferenz über die Ernährung des Pferdes, pp. 140-143. Hannover: Tierärzliche Hochschule Hannover.

Potter, G. D., Hughes, S. L., Jullen, T. R. \& Swinney, D. L. (1992b). A review of research on digestion and utilization of fat by the equine. 1. Europäische Konferenz über die Ernährung des Pferdes, pp. 119-123. Hannover: Tierärzliche Hochschule Hannover.

Potter, G. D., Webb, S. P., Evans, J. W. \& Webb, G. W. (1990). Digestible energy requirements for work and maintenance of horses fed conventional and fat supplemented diets. Journal of Equine Veterinary Science 10, 214-218.

Ralston, S. L. (1988). Nutritional management of horses competing in $160 \mathrm{~km}$ races. Cornell Veterinarian 78 , 53-61.

Reynolds, J. A., Potter, G. D., Odom, T. W., Vogelsang, M. M., Smith, W. B., Nielsen, B. D., Senor, D. M. \& Bird, E. H. (1993). Physiological responses to training in racing two-year old Quarter Horses fed sodium zeolite A. Proceedings of the Thirteenth Equine Nutrition and Physiology Symposium no. 504, pp. $197-202$. Champaign, Ill.: American Society of Animal Science.

Ronéus, B. O., Hakkarainen, R. V. J., Lindholm, C. A. \& Työppönen, J. T. (1986). Vitamin E requirements of adult Standardbred horses evaluated by tissue depletion and repletion. Equine Veterinary Journal 18, $50-58$.

Rose, R. J., Arnold, K. S., Church, S. \& Paris, R. (1980). Plasma and sweat electrolyte concentrations in the horse during long distance exercise. Equine Veterinary Journal 12, 19-22.

Rose, R. J., Purdue, R. A. \& Hensley, W. (1977). Plasma biochemistry alterations in horses during an endurance ride. Equine Veterinary Journal 9, 122-126.

Sallmann, H. P., Kienzlle, E., Fuhrmann, H., Grunwald, D., Eilmans, I. \& Meyer, H. (1992). Einfluss einer marginalen Fettversorgung auf Fettverdaulichkeit, Lipidgehalt und-zusammensetzung von Chymus, Gewebe und Blut (Influence of marginal fat supply on fat digestibility, lipid content and composition in chyme, tissues and blood). 1. Europäische Konferenz über die Ernährung des Pferdes, pp. 124-127. Hannover: Tierärzliche Hochschule Hannover.

Schubert, R. (1990). Zusätzliche Gaben von Vitamin E verbessern die Rennleistung (Vitamin E supplementation improves racetrack performance). Vollblut, Zucht und Rennen 121, 189-190.

Schubert, R. (1991). Nutrition of the performance horse. Influence of high vitamin E doses on performance of racehorse. Proceedings 42nd Annual Meeting of the European Association of Animal Production, p. 538. Rome: Rome Secretariat.

Scott, B. D., Potter, G. D., Greene, L. W., Hargis, P. S. \& Anderson, J. G. (1992). Efficacy of a fat-supplemented diet on muscle glycogen concentrations in exercising thoroughbred horses maintained in varying body conditions. Journal of Equine Veterinary Science 12, 109-113.

Scott, B. D., Potter, G. D., Greene, L. W., Vogelsang, M. M. \& Anderson, J. G. (1993). Efficacy of a fat-supplemented diet to reduce thermal stress in exercising Thoroughbred horses. Proceedings of the Thirteenth Equine Nutrition and Physiology Symposium no. 504, pp. 66-71. Champaign, Ill.: American Society of Animal Science.

Sewell, D. A. \& Harris, R. C. (1991). Lactate and ammonia appearance in relation to exercise duration in the thoroughbred horse. Journal of Physiology 434, 43P.

Sewell, D. A., Harris, R. C. \& Dunnett, M. (1991a). Carnosine accounts for most of the variation in physico-chemical buffering in equine muscle. Equine Exercise Physiology 3, 276-280.

Sewell, D. A., Harris, R. C., Marlin, D. J. \& Dunnett, M. (1991b). Muscle fibre characteristics and carnosine content of race-trained thoroughbred horses. Journal of Physiology 435, $79 \mathrm{P}$.

Sewell, D. A., Harris, R. C., Marlin, D. J. \& Dunnett, M. (1992). Estimation of the carnosine content of different fibre types in the middle gluteal muscle of the thoroughbred horse. Journal of Physiology 455, $447-453$.

Slade, L. M. (1987). Effects of feeds on racing performance of Quarter Horses. Proceedings of the Tenth Equine Nutrition and Physiology Symposium, pp. 585-591. Champaign, Ill.: American Society of Animal Science.

Snow, D. H. \& Harris, R. C. (1989). The use of conventional and unconventional supplements in the thoroughbred horse. Proceedings of the Nutrition Society 48, 135-139.

Snow, D. H. \& Mackenzie, G. (1977). Some metabolic effects of maximal exercise in the horse and adaptations with training. Equine Veterinary Journal 9, 134-140.

Stull, C. L., Rodeik, A. V. \& Arana, M. J. (1987). The effects of common equine feeds on blood levels of glucose, insulin, and cortisol. Proceedings of the Tenth Equine Nutrition and Physiology Symposium, pp. 61-66. Champaign, Ill.: American Society of Animal Science. 
Stutz, W. A., Topliff, D. R., Freeman, D. W., Tucker, W. B., Breazile, J. W. \& Wall, D. L. (1992). Effect of dietary cation-anion balance on blood parameters in exercising horses. Journal of Equine Veterinary Science. 12, 164-167.

Sufit, E., Houpt, K. A. \& Sweeting, M. (1985). Physiological stimuli of thirst and drinking patterns in ponies. Equine Vererinary Journal 17, 12-16.

Topliff, D. R., Lee, S. F. \& Freeman, D. W. (1987). Muscle glycogen, plasma glucose and free fatty acids in exercising horses fed varying levels of starch. Proceedings of the Tenth Equine Nutrition and Physiology Symposium, pp. 421-424. Champaign, Ill.: American Society of Animal Science.

Topliff, D. R., Potter, G. D., Krieder, J. L., Dutson, T. R. \& Jessup, G. T. (1985). Diet manipulation, muscle glycogen metabolism and anaerobic work performance in the equine. Proceedings of the Ninth Equine Nutrition and Physiology Symposium, pp. 224-229. Champaign, I1l.: American Society of Animal Science.

Webb, S. P., Potter, G. D. \& Evans, J. W. (1987a). Physiologic and metabolic response of race and cutting horses to added dietary fat. Proceedings of the Tenth Equine Nutrition and Physiology Symposium, pp. 115-120. Champaign, Ill.: American Society of Animal Science.

Webb, S. P., Potter, G. D., Evans, J. W. \& Green, L. W. (1987b). Digestible energy requirements for mature cutting horses. Proceedings of the Tenth Equine Nutrition and Physiology Symposium, pp. $139-144$. Champaign, Ill.: American Society of Animal Science.

Wolter, R., Durix, A. \& Letourneau, J. C. (1975). Influence du mode de présentation du fourrage sur la digestibilité chez le poney (Forage digestibility in the pony as affected by the physical form of the ration). Annals Zootechnologie 24, 237-242.

Wolter, R., Gouy, D., Durix, A., Letourneau, J. C., Carcelen, M. \& Landreau, J. (1978). Digestibilité et activité biochimiqque intracaecale chez le poney recevant une même aliment complet présenté sous forme granulée, expansée ou semi-expansée (Digestibility and biochemical activity in the caecum of ponies receiving a diet of ordinary pellets, extruded pellets or semi-extruded pellets). Annals Zootechnologie 27, $47-60$.

Wolter, R., Meunier, B., Faucompret, R. De., Durix, A. \& Landreau, J. (1977). Assai d'un aliment complet, granulé ou expansé, en comparaison avec le régime traditionnel chez des chevaux de sport (A complete feed, pelleted feed or expanded feed, compared to traditional feed for riding horses). Revue de Médecine Vétérinaire 128, 71-81.

Worth, M. J., Fontenot, J. P. \& Meacham, T. N. (1987). Physiological effects of exercise and diet on metabolism in the equine. Proceedings of the Tenth Equine Nutrition and Physiology Symposium, pp. 145-151. Champaign, Ill.: American Society of Animal Science. 